\title{
DIRECT MEASUREMENTS BEARING ON THE QUESTION OF THE NIGHTTIME HEATING MECHANISM IN THE IONOSPHERE*
}

\author{
A. F. NAGY \\ Space Physics Research Laboratory, University of Michigan, Ann Arbor, U.S.A. \\ and \\ J. C. G. WALKER \\ School of Physics and Applied Mathematics, The Queen's University of Belfast, N. Ireland \\ (Received 9 August 1966)

\begin{abstract}
Langmuir probe measurements of electron temperature and density were made in the upper $F$-region on two different occasions near local midnight. The experiments were carried out at Fort Churchill, Canada, and at Wallops Island, Virginia. These measurements, which resulted in "vertical" profiles up to high altitudes $(700 \mathrm{~km}$ and $1700 \mathrm{~km}$ respectively), provide an opportunity to study the question of the nighttime ionospheric heat source. Numerical solutions of the steady state heat conduction equation are fitted to the experimental results to provide an evaluation of the relative importance of conduction and local heating. We find that the measured electron temperatures are consistent either with heat conducted down from higher altitudes, or with a local heat source proportional to the ambient electron density. Local heating proportional to the neutral number density is not satisfactory.
\end{abstract}

\section{INTRODUCTION}

Measurements of the electron temperature in the ionosphere during the last few years with Langmuir probes (e.g. Spencer, Brace and Carignan, 1962; Nagy et al., 1963) and by the radar backscatter technique (e.g. Evans, 1965) have clearly shown the absence of thermal equilibrium between the electrons and the neutral particles in the upper $F$-region during both day and night. The purpose of this paper is to present the results of two nighttime, high altitude, electron temperature and density measurements made with cylindrical Langmuir probes and to discuss the nighttime heating mechanism in the light of these results.

\section{EXPERIMENT}

The cylindrical Langmuir probe which was used to measure the electron temperature and density has been described before (Spencer et al., 1965; Nagy and Faruqui, 1965); therefore, it will not be discussed here. The two experiments were carried out at different locations. A Javelin sounding rocket, NASA 8.20, carrying the first set of probes, was launched from Fort Churchill, Canada, at 23:14 Central Standard Time on November 6, 1964. The second set of measurements was obtained by a Langmuir probe carried on NASA 11.03, launched from Wallops Island, Virginia, at 00:33 Eastern Standard Time on May 30,1965. The electron temperature and density information obtained from these flights is shown in Figs. 1-4. The electron temperature profiles are obtained by drawing a line through a very large number of data points (over 1000 points per flight). The standard deviations of the data points about these curves are indicated by the bars. The

* Presented at the COSPAR Seventh International Symposium, Vienna, 1966. 

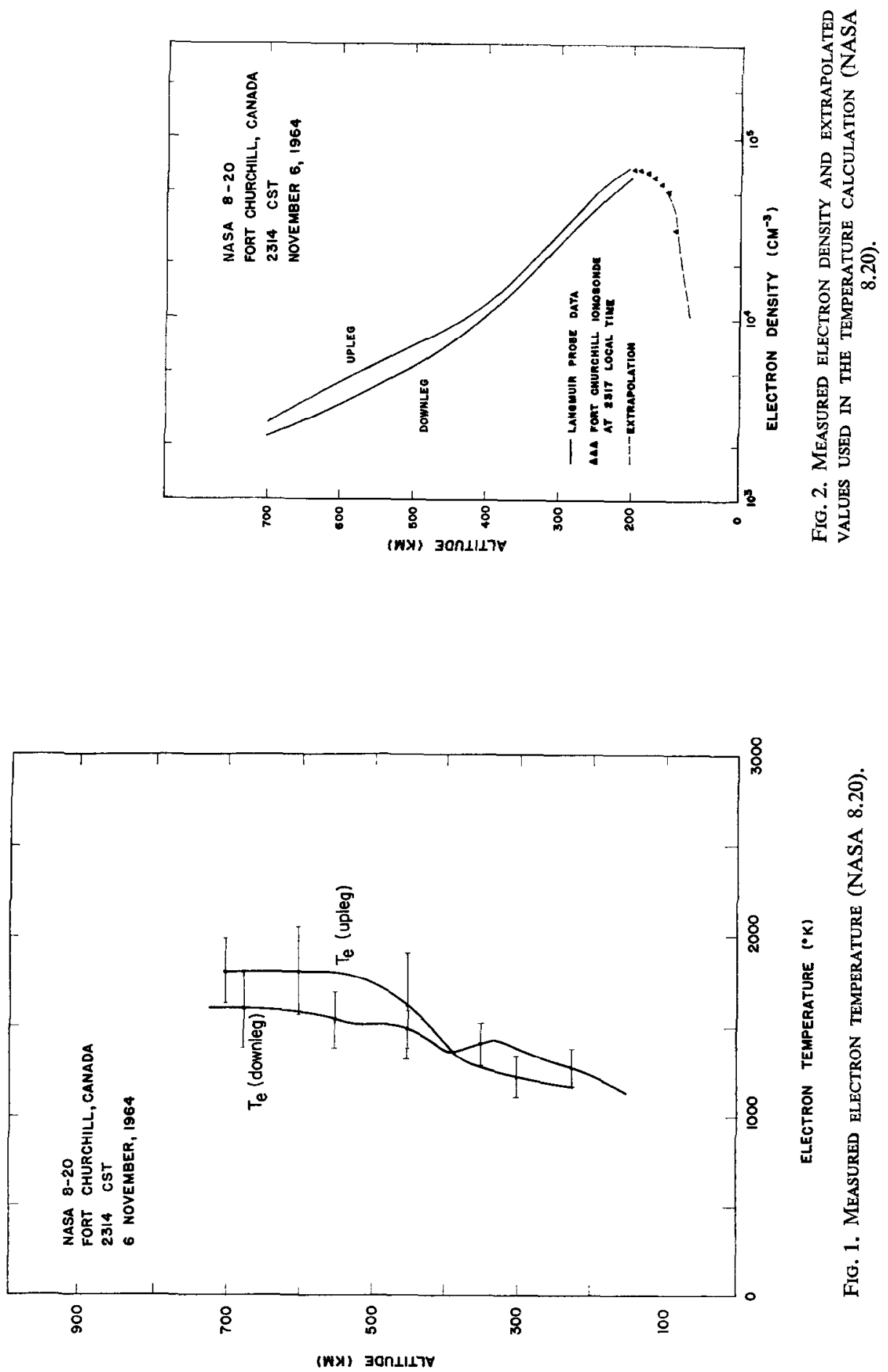

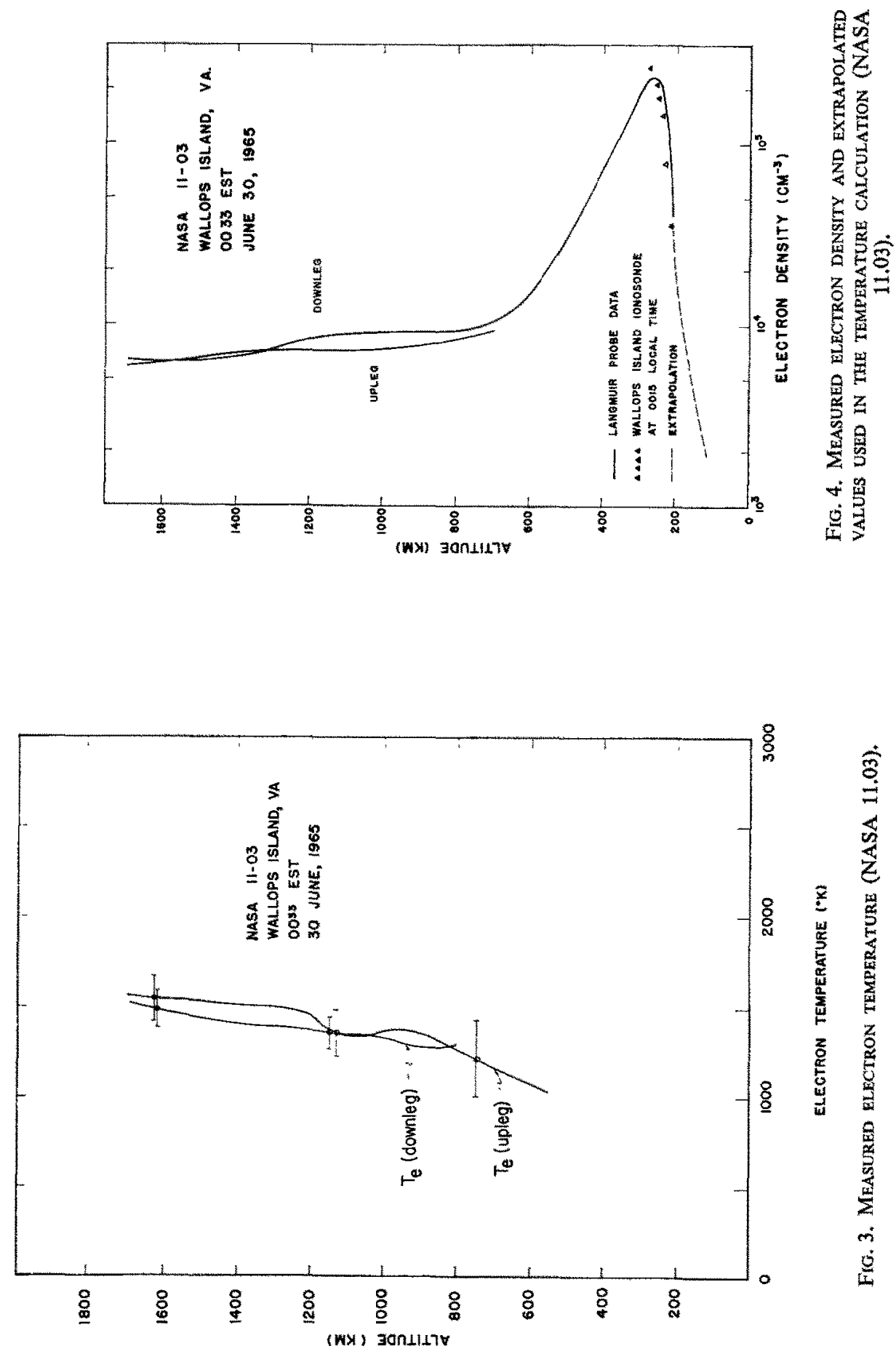
deviations for 8.20 are considerably larger than is common for this measurement technique mainly because of unfavourable probe orientation and rocket roll rate. The results of the ionosonde soundings, taken at the place and time of launch, are shown along with the density results for comparison.

\section{CAlculations}

Using the measured electron densities and the Jacchia (1964) model of the neutral atmosphere appropriate to the time and place of the measurements, we have calculated theoretical electron temperature profiles allowing for local heating, cooling, and thermal conduction in the electron gas. This calculation is described by Dalgarno, McElroy and Walker (1967) and we have made no significant changes in the computer program.

Geisler and Bowhill (1965) suggest that during the night the ionosphere assumes the role of heat sink for the thermal energy stored in the protonosphere, the energy being conducted downward along magnetic field lines. Electrons of kilovolt energies have also been suggested (Willmore, 1964) as a possible nighttime heat source. Recent measurements (Serbu, 1965; Sagalyn and Smiddy, 1966) have established the presence of soft electrons $(\sim 5-10 \mathrm{eV})$ in the protonosphere, and a flux of soft electrons should also be considered as a candidate for the nighttime heating mechanism (Brace, Spencer and Dalgarno, 1965).

As a rough representation of these possible heat sources we considered the following three models:

(a) No local heating but conduction of an arbitrary heat flux from above;

(b) no conduction of heat from above but a local heat source proportional to the neutral particle density;

(c) no conduction of heat from above but a local heat source proportional to the electron density.

The heat flux in (a) and the proportionality constants for the local heating terms in (b) and (c) were selected so as to obtain the best fit to the measured electron temperatures. We are mainly interested in finding out whether or not the data can distinguish between heat sources as disparate as these. The identification of these local heat sources as due to hard or soft electron fluxes is not our principal concern here.

\section{DISCUSSION}

The results of these calculations are compared with the experimental results in Figs. 5 and 6 . The theoretical temperature profiles obtained by assuming heat conduction from the protonosphere as the only heat source agree most closely with the experimental results. However we probably cannot, on the basis of these measurements alone, rule out the heat source proportional to electron density. The best fit to the data would no doubt be obtained by a judicious mixture of the three heat sources we have considered. We cannot look for too close a correspondence between theory and measurement because the calculations yield the temperature profile along a magnetic field line at an instant in time, whereas the rocket profiles do not follow the field lines exactly, and the flight times of 8.20 and 11.03 were about $15 \mathrm{~min}$ and 26 min respectively.

The temperature gradients at the peak altitudes in the "conduction only" case correspond to a downward heat flux of about $9.9 \times 10^{8} \mathrm{eV} \mathrm{cm}^{-2} \mathrm{sec}^{-1}$ for the high latitude experiment (NASA 8.20) and $2 \times 10^{8} \mathrm{eV} \mathrm{cm}^{-2} \mathrm{sec}^{-1}$ for the midlatitude experiment (NASA 11.03). First order calculations by Geisler and Bowhill (1965) indicate that a flux of $10^{8} \mathrm{eV} \mathrm{cm}^{-2} \mathrm{sec}^{-1}$ can be maintained throughout most of the night at midlatitudes, 

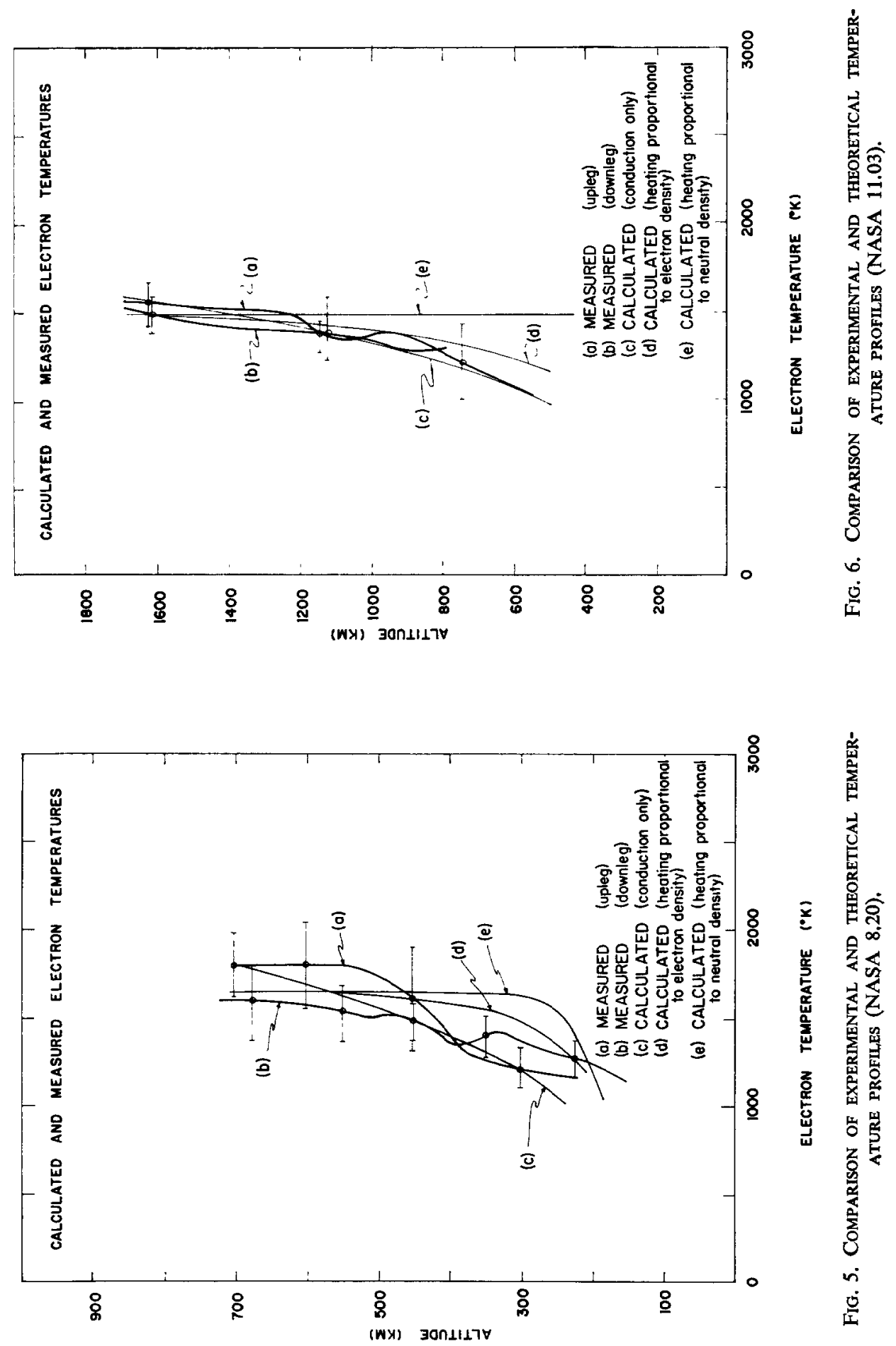
which is in fair agreement with our results for the midlatitude case. The larger heat flux corresponding to the Fort Churchill results may arise because the high latitude field tubes, with a larger volume, can have more energy stored in them and can, therefore, support a larger flux throughout the night.

The heat source proportional to electron density provides a satisfactory alternative explanation of the data. This source has an integrated value of $3.54 \times 10^{9} \mathrm{eV} \mathrm{cm}^{-2} \mathrm{sec}^{-1}$ for flight 8.20 and $1.21 \times 10^{9} \mathrm{eV} \mathrm{cm} \mathrm{sec}^{-1}$ for 11.03. A soft electron flux corresponding to these values is not likely to produce a nightglow in excess of the measured intensities since the incident electrons lose most of their energy by heating the ambient electron gas (Dalgarno, 1964).

As the electron density decreases at low altitudes the electron heat source provided by energetic charged particle bombardment must also decrease. To correspond to this situation our heat source (b) (proportional to neutral density) was set equal to zero below $240 \mathrm{~km}$. The calculated temperature profile above $300 \mathrm{~km}$ is quite insensitive to the altitude and shape of the cut off. Since the calculated profiles are essentially isothermal above $300 \mathrm{~km}$ while the measured profiles clearly are not, we feel that the heat source proportional to neutral density can be excluded. The height integral of this heat source is $2.59 \times 10^{9} \mathrm{eV} \mathrm{cm}^{-2} \mathrm{sec}^{-1}$ for NASA 8.20 and $5.44 \times 10^{9} \mathrm{eV} \mathrm{cm}^{-2} \mathrm{sec}^{-1}$ for NASA 11.03, but these values are very sensitive to how we cut the heat off at low altitudes.

\section{CONCLUSION}

More accurate high altitude rocket borne experiments will be needed to provide further information on the nighttime heating mechanism. Satellite measurements are not likely to be useful in this regard for mid and high latitude studies, because they yield profiles which are nearly horizontal, while we approach the problem of the nocturnal heat source by calculating the profile of electron temperature along a magnetic field line. However, satellite results can be used to see whether heat is conducted towards the equatorial ionosphere from midlatitudes (BRACE et al., 1967). Results from backscatter measurements may be useful for vertical studies, and we are looking at published backscatter data.

Acknowledgements-The authors wish to express their appreciation to the staff of the Space Physics Research Laboratory of the University of Michigan for designing and building the flight hardware and carrying out the data reduction and numerical analysis.

This work was supported by NASA Headquarters under Grant NsG-525.

\section{REFERENCES}

Brace L. H., RedDY B. M. and MAYR H. G, 1967. J. geophys. Res. In press.

Brace L. H., Spencer N. W. and Dalgarno A. 1965. Planet. Space Sci. 13, 647.

Dalgarno A., 1964. Annls Géophys. 20, 65.

Dalgarno A., McElroy M. B. and Walker J. C. G. 1967. Planet. Space Sci. In press.

Evans J. V. 1965. Planet. Space Sci. 13, 1031.

GeISLER J. E. and Bowhill S. A. 1965. J. atmos. terr. Phys. 27, 1119.

JACCHIA L. G. 1964. Smithsonian Astrophys. Obs. Spec. Rep. No. 170.

Nagy A. F., Brace L. H., Carignan G. R. and Kanal M. 1963. J. geophys. Res. 68, 6401.

NAGY A. F. and FARUQui A. Z. 1965. J. geophys. Res. 70, 4847.

SAGALYN R. C. and SMIDDY M. 1966. Space Research VI.

SERBU G. P. 1965. Space Research V, 564. North-Holland, Amsterdam.

SPenCer N. W., Brace L. H. and Carignan G. R. 1962. J. geophys. Res. 67, 157.

SPenCer N. W., Brace L. H., Carignan G. R., TAeusch D. R. and NiEmanN H. 1965. J. geophys. Res. 70, 2665 .

Willmore A. P. 1964. Proc. R. Soc. A281, 140. 
Резюме-Были сделаны ланмьоровские пробные измерения әлектронной температуры и плотности в верхних слонх ионосферы, в двух равличных сгучаях, около полуночи по местномувремени. Испытания проводилиеь в "Форт черчилль», Канада и на острове "Уоллопс", Виргиния. Әти измерения, которые результировали в «вертикальных» профилях вплоть до больших высот (700 и 1700 км соответственно), способствуют возможности изучения вопроса ночного источника тепла ионосферы. Цифровые решения уравнения теплопроводимости в установившемся состоянии приурачиваются к результатам испытаний, тобы обеспечить оценку относительной ванности проводимости и местного нагревания. Мы вамечаем, что пзмеряемые әлектронные температуры совместимы как с теплом, проводимым с больших высот, так и с местным источником тепла, пропорционального окружающей әлектронной плотности. Местное нагревание, пропорциоиальное нейтральному числу плотности, считается неудовлетворительным. 